\title{
Job Status of Women Head Clergy: Findings from the National Congregations Study, 1998, 2006, and 2012
}

\author{
Catherine Hoegeman \\ Department of Sociology and Anthropology, Missouri State University, Springfield, MO 65897, USA; \\ choegeman@missouristate.edu
}

Received: 31 July 2017; Accepted: 16 August 2017; Published: 19 August 2017

\begin{abstract}
This paper investigates occupational gender inequality among head clergy in U.S. religious congregations. Prior research emphasized the stratification of the clergy occupational structure and the under-representation of women in head clergy positions. This paper focuses on women who are leading congregations. Data are from the National Congregations Study $(1998,2006$, and 2012). I review the representation of women among head clergy, investigate the differences in congregational characteristics between those led by men and women, and explore whether men or women are more likely to have positions with non-standard employment forms. Findings show a mixed picture regarding equality for women clergy. By 2012, while women are still less likely than men to be head clergy, among head clergy there is not a significant difference between women and men in the likelihood of being a senior pastor (supervising other clergy). Also, there are no significant differences related to non-standard employment. The only significant congregational member characteristic is that women are more likely to lead predominantly white congregations. However, in 1998, 2006, and 2012, women were consistently significantly more likely than men to lead smaller congregations. While there may be few other differences between men and women head clergy job statuses, congregation size is arguably what matters most. Women's lack of representation in larger congregations suggests continued gender inequality among head clergy.
\end{abstract}

Keywords: women clergy; religious congregations; occupational sex segregation

\section{Introduction}

In the last several decades, research on gender inequality in the workplace explored how overt forms of gender-based job discrimination may be less common than they used to be, but implicit (unintentional) bias and organizational and occupational structures still limit women's opportunities in the workplace (Bendl and Schmidt 2010; Bielby 2000; Cohen et al. 2009; Cook and Glass 2014; Reskin 2000; Ryan and Haslam 2007; Tomaskovic-Devey 1993; Williams 2000).

There is a solid body of research on women clergy focusing on the under-representation of women in the clergy in general, and among head clergy, in particular (e.g., Carroll et al. 1981; Chang and Bompadre 1999; Chang 2005; Finlay 1996; Lehman 1981; Nesbitt 1997a, 1997b, 1997c; Sullins 2000; Wind and Rendle 2001). The continued under-representation and stratification of women within the clergy occupational structure is an important area for additional study. However, some women have made it past the "stained glass ceiling" and are serving as head clergy of religious congregations. Therefore, this article explores important questions related to these women and their congregations. To what extent are jobs in the top tier of the clergy occupational structure segregated by gender? If congregations are viewed from a more secular perspective as more or less desirable job sites, are there notable differences in the types of congregations led by men versus women? Do job characteristics such as being paid or not and fulltime/part-time status vary by gender?

Research on women clergy and clergy gender differences tends to focus on individual clergy as the unit of analysis, within the context of the organizational and occupational structure 
(e.g., Carroll et al. 1981; Chang 2005; Charlton 1997; Finlay 1996; Lehman 2002; McDuff and Mueller 1999; McDuff and Mueller 2000; McDuff 2001; Nesbitt 1993; Nesbitt 1997a, 1997b, 1997c; Sullins 2000; Wildhagen et al. 2005; Zickmund et al. 1998). This article adds to the body of research that focuses on congregational characteristics and congregations as the unit of analysis, while still using clergy as the key variable (e.g., Adams 2007; Konieczny and Chaves 2000; Lehman 1981; Mueller and McDuff 2002).

This article provides an important update to research on clergy gender inequality by using a nationally representative sample of congregations, the 1998, 2006, and 2012 waves of the National Congregations Study (NCS) (Chaves et al. 2014). It expands on the 1998 NCS research on women clergy by including 2006 and 2012 data and refines earlier NCS-based studies by limiting the sample to congregations whose religious traditions or denominations ordain women. It also expands on earlier clergy gender inequality research by exploring non-standard forms of employment.

I briefly discuss the representation of women as head clergy of congregations. The primary analyses compared the congregational characteristics and job-type statuses of men and women head clergy.

My findings show that based on the most recent NCS data (2012), 14 percent of congregations have a female leader. This has not changed since 1998. In 2012, women were more likely to lead congregations that are: smaller; theologically moderate or liberal; white mainline or Black protestant; and rural or urban. Compared to the earlier 1998 and 2006 data, women are more likely to be at congregations with a primarily $(>80 \%)$ white membership. In 2012 , among head clergy, women were just as likely as men to be senior pastors, be paid, work fulltime, serve multiple congregations, or be bi-vocational.

\section{Background}

\subsection{Occupational Feminization and Organizational Gender Inequality}

Tolbert and Hall (2016) asserted that foundational work on gender inequality in organizations comes from the 1980s and 1990s. Reskin and Roos (1990) discussed how jobs in the United States have historically been segregated by sex. While women made inroads into some male dominated occupations during the 1970s, most occupations remained dominated by one sex or the other. Reskin and Roos see occupational composition as a result of a "dual-queuing process: labor queues order groups of workers in terms of their attractiveness to employers, and job queues rank jobs in terms of their attractiveness to workers" (1990, p. 29). Preferred workers get the preferred jobs, least preferred workers may remain unemployed, and least desirable jobs may remain unfilled. As an occupation becomes feminized, the theory suggests two ways the structure of the job queue could change. In some cases men leave the job for better ones, making room for women to enter, and in other cases an influx of women degrades the job status causing men to leave.

Nesbitt (1997b) examination of the feminization of clergy draws substantially from Reskin and Roos (1990), as do other more recent studies on organizational gender inequality (e.g., Adams 2005; Gatta and Roos 2005; Michaelson 2013; Roth 2004; Skuratowicz and Hunter 2004), confirming the foundational nature of Reskin and Roos' work. Reskin and Roos found that women had not yet made significant inroads into the clergy, but they anticipated that the clergy would become a more feminized occupation. One indication of possible feminization of the clergy is the increase in women in seminaries. Women's seminary enrollment went from 10 percent in 1972, to 19 percent in 1979 (Taylor 1979), to 29 percent in 1989 (King 1990), and finally to 34 percent by 1998 (Zyniewicz and Aleshire 1999). In 2015, 17 years later, women remained at one-third (33 percent) of seminary students (ATS 2015).

Reskin and Roos (1990) also explored how occupations become internally segregated, especially when women enter the occupation in greater numbers. Men retain or move into the higher status jobs within an occupation and women are left with the lower status jobs. Chang (2005) described most religious denominations as having a pyramid clergy status structure that is related to congregation size. Upper-level clergy positions are senior pastors of large churches (one or more associate or special 
ministry pastors). Mid-level positions are associate pastors of large congregations or sole pastors of medium size congregations. Lower-level positions are sole pastors of small congregations. Chang described non-congregational ministries (e.g., hospital chaplains, campus ministers) as less desirable or lower status. Nesbitt (1997b) supports this suggesting that congregational settings have more authority, personal and organizational resources. Some clergy choose non-congregational positions, but others are pushed into these jobs because they cannot find a congregational position they are willing to take. Finally, some clergy cannot find jobs within the clergy occupational structure and must resort to secular work.

Prior clergy studies consistently showed that women were more likely to hold the lower ranked positions either as sole pastor of medium or smaller congregation, associate pastor or specialized minister (e.g., youth minister), or in a non-congregational position. Women were also more likely than men to be in non-congregational positions (Carroll et al. 1981; Chang and Bompadre 1999; Chang 2005; Finlay 1996; Lehman 2002; Nesbitt 1993; Nesbitt 1997c; Sullins 2000; Wind and Rendle 2001). The question remains as to why. Even if job candidates actively choose non-congregational positions and are not just accepting them because they cannot find suitable pastor positions, gender equity would suggest that men would be as likely as women to make this choice. Therefore, the fact that these positions are more likely to have women suggests occupational gender inequality. Regarding the difference in opportunity for women between senior pastor and sole pastor, Lehman (1981) and Sullins (2000) found that congregation members were less likely to support a woman head clergy for congregations with multiple staff members.

While the clergy occupation has become more feminized, and women have gained some access to clergy positions in general, women are still under-represented as congregation leaders. Nesbitt (1997b) noted that efforts by some denominations to increase opportunities for women clergy helped women get entry level positions, but not necessarily advance to higher level positions. The clergy occupation remains internally stratified.

Tomaskovic-Devey (1993) described processes that create the segregated job queue. He focused on demand side processes in the work place rather than supply side issues of individual human capital characteristics such as education and socialization. Status closure is an overt form of discrimination, sorting people into jobs based on status characteristics such as race and gender. For example, denominations that have doctrines or policies that explicitly prohibit ordaining women or do not allow them to serve as head clergy. In denominations that do ordain women, if there is a bias against women supervising male clergy or other male staff, status closure could prevent women from being in senior clergy positions while they might be accepted as sole pastors.

Status composition is a less overt process by which an occupation's functions become associated with a particular gender or racial group. Occupations are perceived as higher or lower status based on the status of the group the occupation is associated with. (Nesbitt 1993; 1997b) described an example of status composition within the clergy occupational structure where the addition of a lower level ordination status path, such as deacon or minister of education, disproportionately tracks women into the lower track and tends to associate women in the main ordination track with those in the lower one. This is an informal process, not official policy, but it results in a further gender segregated occupation.

This article focuses on differences in congregation types and job statuses between women and men who hold head clergy positions. However, I conduct a preliminary descriptive analysis using the three waves of the NCS to show the difference in representation among head clergy between men and women. Given that seminary enrollment remains at one-third women and the dynamics of an internally segregated job structure, I anticipate the following:

Hypothesis 1. Women are less likely than men to be the head clergy of a congregation.

One of the primary analyses focuses on job status characteristics and includes an aspect of the stratified clergy occupational structure and distinguishes among head clergy. The senior pastor 
(having subordinate ministers) is a higher status than the sole pastor who is the only minister. Women's tendency to occupy the lower levels of the clergy occupational structure suggest:

Hypothesis 2. Women are less likely than men to be senior pastors.

\subsection{Congregational Characteristics as Measures of Clergy Job Status}

For women who are at the upper level of the clergy occupational structure, as either senior or sole pastor, job stratification can also be based on the different types of congregations. Nesbitt (1997b) asserts that the clergy as a profession cannot be completely equated with other professions because of the "eschatological element" (p. 6). Individuals make decisions about entering the profession in general, and choices about specific job placements based on religious and spiritual motives; feeling called or following God's will. Clergy might not be primarily interested in evaluating positions based on secular job status factors and some clergy might seek out low status congregations as being more in need. However, Nesbitt acknowledged that higher level positions might offer more opportunity for "autonomy and authority," (p. 7) which can enhance the ability to serve. In their analysis of clergy job searches, Wildhagen et al. (2005) also used what could be considered secular characteristics to describe clergy positions. Chang (2005) review of clergy careers presents the dual perspective of ministry as calling and career and acknowledges that clergy evaluate their job positions using some of the same criteria as their secular counterparts. Whether using secular or sacred norms, an equitable distribution of clergy across congregation of higher and lower status should not reflect any systematic differences based on clergy gender.

Some congregational characteristics provide measures of the status, prestige, or desirability of the congregation as a workplace, and congregational members as clientele. A large congregation with wealthier members can be considered more prestigious. Congregations with families, a balance of men and women, younger and more educated members may be more vibrant which might make the congregation a more desirable job. This mix of members might bring more resources in terms of time, energy, and expertise.

Size is related to resources in general (e.g., total income, number of staff), therefore, congregational size is an important indicator of the head clergy job status. Chang (2005) specifically used congregation size to describe the pyramid structure ranking clergy positions. Many small congregations cannot afford a fulltime pastor so the religious labor market is comprised of both fulltime and part-time jobs for clergy, as well as both paid and unpaid positions. Chang (2004) concluded that even though the overall ratio of clergy to congregations suggests an oversupply of clergy, there is a shortage of clergy, including women, willing or able to serve smaller congregations. Even though there might be a demand for clergy, a supply side perspective suggests that one reason the number of women head clergy has not increased may be because women are unwilling to take positions at smaller congregations.

Mueller and McDuff (2002) explored whether or not clergy jobs with lower monetary benefits were compensated for by better non-monetary benefits. Larger congregations with bigger budgets are generally considered a better job situation. They found employment relationship characteristics (intrinsic rewards, material rewards, support, and fair treatment) were positively associated with larger congregations and bigger budgets. This dispels the differential compensation argument. Congregations are either good or bad job situations and larger congregations are usually better.

Using the 1998 NCS data, Konieczny and Chaves (2000) found that women were more likely to lead smaller congregations and less likely to have fulltime staff. Congregations with high proportions of women members were more likely to have a woman head clergy and congregations with affluent or younger members were less likely to have a woman head clergy. Adams (2007) and Konieczny and Chaves reported that, compared to those led by men, women-led congregations had fewer resources-smaller budget, lower member income, fewer or no staff.

The location of the congregation could also influence its desirability; a suburban congregation conceivably being more desirable than an urban or rural one (Adams 2007). Lehman (1981) suggested 
that small communities with declining membership would be more open to a woman head clergy, but he counter-proposed that smaller (rural) communities could be more conservative, making them more resistant to women clergy. Konieczny and Chaves (2000) indicated that women head clergy were more likely in urban areas and Adams (2007) found them less likely in the suburbs.

Hypothesis 3. Congregations led by women head clergy are likely to have lower status characteristics than congregations led by men.

\subsection{Nonstandard Forms of Employment}

Kalleberg (2000) described nonstandard forms of employment as including part-time, contract, and temporary work. Drawing on Piore (1971), Kalleberg et al. (2000) described the dual labor market and discussed primary and secondary job markets. They distinguished good jobs from bad jobs. Bad jobs have characteristics such as: low pay; no health insurance; and no pension benefits. Their study indicated that nonstandard jobs are more likely to have bad job characteristics. They also concluded that women and minorities were more likely than white men to have nonstandard (bad) jobs. Zickmund et al. (1998) found that women clergy were underpaid and under-employed relative to men, and more likely to work part-time.

As part of a study of senior and sole pastors, Carroll (2006) explored the characteristics of clergy and their work, including their job status in terms of being fulltime/part-time, bi-vocational, or lay (non-ordained). The only comparison he made between men and women was regarding salaries. For senior and sole pastors whose salaries were under $\$ 60,000$, those with similar education and years of experience in comparable congregations had comparable salaries. The study did not include the high-end of the salary scale, which could be male dominated. Carroll noted that while women clergy seemed to get equal pay for equal work, the question remained regarding whether or not they had equal access to higher paying congregations.

Carroll (2006) also commented on the increase in the number of bi-vocational pastors Bi-vocational pastors have another job, which is often their primary paying position. For someone with another job the clergy position could be part time or fulltime, paid or unpaid. This might suggest that the clergy position does not provide the income/benefits necessary for it to be the person's only job. Another common situation is when clergy serve more than one congregation. The NCS survey question asks if the head clergy "serves another congregation besides this one." This suggests the person is serving part-time at two or more independent congregations which would be a non-standard employment form. If person has a single position as head clergy of a multi-site congregation, which could be considered a more prestigious position, this would more likely be described as serving multiple locations, rather than multiple congregations.

Hypothesis 4. Women head clergy are more likely than men to experience nonstandard forms of congregational employment (unpaid, part-time, bivocational, multiple congregations).

\section{Data and Methods}

\subsection{Data}

Data are from the 1998, 2006, and 2012 waves of the National Congregations Study (NCS) (Chaves et al. 2014). Each wave of the NCS used hyper-network sampling to generate a nationally representative sample of congregations. This method creates a random sample of congregations by identifying the congregational associations of a random sample of individuals. The General Social Survey (GSS) is a national random sample of non-incarcerated adults in the United States conducted every two years. In 1998, 2006, and 2012, the GSS asked respondents who reported attending religious services at least once a year to identify their congregations. This created three separate, random samples of congregations nation-wide. There are 1234 total congregations in the 1998 sample. The 2006 sample includes a new cross-section of 1244 congregations as well as panel component with 256 congregations 
from the 1998 sample, creating a sample size of 1506. The 2012 sample includes 1331 congregations (Chaves et al. 1999; Chaves and Anderson 2008; Chaves and Anderson 2014).

Hyper-network sampling results in a probability-proportionate-to-size sample; larger congregations had more of a chance of being nominated than smaller ones. In addition, more than one GSS respondent could nominate the same congregation. When weighting is applied only to account for duplicate nominations, people (attendees) are the unit of analysis. When weighting is applied to account for the probability-proportionate-to-size sample, congregations are the unit of analysis. An example of the difference between the two sampling weights is the congregation weight identifies how many congregations have a female leader, while the people weight identifies how many people attend a congregation with a female leader. My unit of analysis is the head clergy (and his/her congregation) so I used the congregation weight.

The NCS was an hour long survey (conducted by phone or in-person) with a key informant from each congregation. The key informant was usually the head clergy person, or someone else familiar with the congregation such as a staff member or congregation elder. Questions included items describing the congregation size; denomination or tradition; leadership, staffing and administration; worship style; types of groups; member demographics; and relationships with the broader society (social services, political involvement, ecumenical activity, etc.).

This article focuses on more implicit forms of occupational inequality rather than processes that explicitly exclude women from head clergy positions. Therefore, I only included congregations associated with the denominations or religious traditions that ordain women and allow them to serve as head clergy. This excludes Roman Catholic, Southern Baptist, Missouri Synod Lutheran, Mormon, Orthodox Jewish, Eastern Orthodox, and Islamic congregations. I also removed congregations if clergy sex was missing, the position was vacant, or there were co-pastors (which precluded identifying a single "head" clergy). The final data set includes 710 cases in 1998, 879 cases in 2006, and 792 cases in 2012.

\subsection{Analyses}

I used bivariate statistics as preliminary analysis to compare the likelihood of men and women clergy having different job characteristics or to lead congregations with different characteristics. I used a Chi-square test for nominal variables and t-test for interval variables and used the congregation sampling weight. For analyses 2 and 3, the primary focus is using regression models. All of the dependent variables are dichotomous so I used logistic regression and reported odds ratios. Congregational income had notable levels of missing data so I imputed the missing values ${ }^{1}$. Size (number of adults) and income have skewed distributions so I used the natural log of these variables. I ran the regressions without weights and followed the method outlined by Winship and Radbill (1994) which compensates for not using weights by including the necessary interaction terms between number of adults (because sampling weight is based on size as measured by number of adults) and variables specified by the Winship and Radbill diagnostics.

\subsubsection{Analysis 1}

Analysis 1 addressed hypotheses 1 . I used simple frequencies to show the relative percentage of men and women for each wave of the NCS, 1998, 2006, and 2012, and tested for a statistically significant difference between years. While my primary focus is on clergy gender, I incorporated an intersectional perspective by exploring race and gender together.

1 In the regression analysis, when controlling for other factors, income was only marginally significant in two of the models. I ran analyses leaving out income and obtained similar results so the missing/imputed data is not a concern. 


\subsubsection{Analysis 2}

Analysis 2 addressed hypothesis 3 and explored differences in the types of congregations led by men and women head clergy. Congregational characteristics were the independent variables used to predict head clergy sex as the dependent variable. First I analyzed the combined 1998-2012 data set and included year as an independent variable to see if there was an overall significant difference based on year. Then I analyzed 1998, 2006, and 2012 data separately and compared the results to assess change over time. Congregational resource measures included size (number of adults) and congregational income. Demographic characteristics of congregation members provided another way to classify the status of a congregation. Higher status clergy jobs could be defined by higher percentages of affluent or educated members, lower percentages of poorer members, more gender- and age-balanced memberships, and higher percentages of "typical" families (two parents and children) (Konieczny and Chaves 2000). The variables describing these measures are the percentage of congregation members who are: female; under age 35; over age 60; part of a two-parent family with children; have a bachelor's degree; are high income; and are low income ${ }^{2}$. Congregations in the suburbs might be more desirable than rural or urban congregations (Adams 2007).

Following prior NCS analyses, I included several additional control variables. The religious tradition measure is similar to the categorization developed by Steensland et al. (2000) which is commonly used in research on religious congregations ${ }^{3}$. Since I removed Catholic congregations, the remaining categories include: white evangelical protestant; white mainline (liberal) protestant; Black protestant; and non-Christian. Women head clergy are more likely in mainline protestant denominations (Adams 2007; Konieczny and Chaves 2000). Evangelical (conservative) protestants, Black protestant congregations, and congregations adhering to Biblical inerrancy are less likely to have women head clergy (Adams 2007). The congregation's overall theological orientation (liberal, moderate, or conservative) is a separate concept from religious tradition. Theological orientation tends to vary between religious traditions and there is also notable theological variation within religious traditions. Congregations with a more liberal theological orientation would be more likely to have women head clergy. Following Konieczny and Chaves (2000), I included a binary measure indicating whether or not the congregation is in the South and measure congregational ethnic diversity by including a variable indicating whether or not at least 80 percent of the congregation is white.

\subsubsection{Analysis 3}

Analysis 3 used 2006 and 2012 data to address hypotheses 2 and 4, whether or not clergy gender (the independent variable) influences different job characteristics. Each of six regression models has a different dichotomous dependent variable describing a specific job characteristic. The first one distinguishes senior from sole pastor-does the congregation have paid ministry staff besides the pastor? The next four variables describe standard versus nonstandard forms of employment. Is the head clergy paid? Is the head clergy fulltime or part-time? Does the head clergy serve another congregation? Does the head clergy work at another (secular) job? The last variable is a combined measure indicating, whether or not the clergy has a standard job. This composition variable requires the position be fulltime and paid. The person can serve multiple congregations, but cannot be bi-vocational.

Control variables include other clergy characteristics that could affect the characteristics (status) of their positions: age, race, tenure, whether or not the person attended seminary or graduate school; and being ordained or not. Whether or not the clergy position is fulltime is one of the dependent variables, but it is likely to affect the other job characteristics (e.g., fulltime positions are more likely to be paid)

2 In 1998 and 2006 the high income threshold was over $\$ 100,000$ per year and the low income threshold was below $\$ 25,000$. In 2012 the high income threshold was over $\$ 140,000$ per year and the low income threshold was below $\$ 35,000$ a year.

3 Steensland et al. (2000) code Black protestant churches based only on denominational affiliation with a historically black Church. The NCS also includes any protestant church where over 80 percent of the members are African-American. 
so I include it as a control in the other models. I also control for several congregational characteristics. Congregation size (measured by number of adults) and income influence the likelihood of being able to provide clergy benefits such as pay, fulltime status, and the congregation having ministry staff besides the pastor. The location of the congregation, urban, suburban, or rural, affects the possibility of a clergy person serving another congregation or having another job. Rural clergy might be more likely to be bi-vocational. Being in a rural area might mean congregations are small and a pastor needs to serve multiple congregations. Conversely, rural congregations could be further apart, making it more difficult to lead multiple congregations.

Denominational affiliation could affect placement and pay policies. The NCS religious tradition measure collapses the hundreds of specific denominations into a few broader categories. Not all of the denominations within a given religious tradition group will have the same specific doctrines and policies, but doctrine is an important factor used to combine denominations into larger religious tradition groups so controlling for potentially similar doctrinal perspectives is relevant. The non-Christian category includes more diverse groups whose doctrines and policies will obviously vary. Because of the internal diversity and small size of this category, I do not focus on this group in discussing results, but I retain it in the analysis as a control.

\subsection{Variables}

Table 1 shows the years included and variables used for each analysis. Clergy gender is the dependent variable for analysis 2 because I am exploring what congregational factors influence the likely of having a male or female head clergy. For analysis 3, the goal is to see how clergy gender influences job status so clergy gender is the primary independent variable. The six different job characteristics are the dependent variables. Control variables include additional clergy and congregational characteristics.

Table 1. Variables.

\begin{tabular}{|c|c|c|c|}
\hline Analysis-Years & Dependent Variables & Independent Variables & Control Variables \\
\hline (1) $1998,2006,2012$ & Clergy Gender & Year & \\
\hline \multirow[t]{2}{*}{ (2) 1998, 2006, 2012} & Clergy Gender & Number of Adults & \\
\hline & & $\begin{array}{c}\text { Congregation Income } \\
\text { Total Staff } \\
\text { Congregation Demographics } \\
\% \text { Female } \\
\% \text { Under age } 35 \\
\% \text { Over age } 60 \\
\% \text { Two-parent family } \\
\% \text { Bachelor's degree } \\
\% \text { Income }>\$ 100,000 \\
\% \text { Income }<\$ 25,000 \\
\geq 80 \% \text { white } \\
\text { Theology } \\
\text { Religious Tradition } \\
\text { South } \\
\text { Urban/Rural/Suburban }\end{array}$ & \\
\hline (3) 2006,2012 & Other Ministry Staff & Clergy Gender & Clergy Demographics \\
\hline & $\begin{array}{c}\text { F/T position } \\
\text { Paid } \\
\text { Multiple congregations } \\
\text { Bi-vocational } \\
\text { Standard position }\end{array}$ & & $\begin{array}{c}\text { Race } \\
\text { Age } \\
\text { Graduate school } \\
\text { Ordination status } \\
\text { Tenure } \\
\text { Number of Adults } \\
\text { Congregation Income } \\
\text { Religious Tradition } \\
\text { Urban/Rural/Suburban }\end{array}$ \\
\hline
\end{tabular}




\section{Results}

\subsection{Analysis 1-Representation of Women as Head Clergy}

Table 2 shows the numbers and percentages of head clergy by race and gender for each wave of the NCS. Hypothesis 1 is supported in that women are notably under-represented, comprising about 14 percent of head clergy. There is no change between 1998 and 2012. The dip for women in 2006 is not statistically significant. This result is most likely due to sampling error, which emphasizes the importance of testing for statistical significance and the value of multiple waves of the NCS. The lack of statistical significance indicates no real change, which is confirmed by the more stable picture presented when looking at possible change over the longer period, between 1998 and 2012. Chaves and Anderson (2008) highlighted the need to consider particular religious denominations and religious traditions in addition to the aggregate analysis. According to Chaves and Anderson, theologically liberal traditions did show an increase in female head clergy between 1998 and 2006. Therefore, is it possible that the 2006 sample under-represented liberal congregations with female head clergy.

From an intersectional perspective, while the primary divide is based on gender-with men significantly outnumbering women - the relative percentages suggest that racially diverse women are less represented than white women. However, the racial differences among women are not statistically significant, possibly due to the relatively small sample sizes for women.

Table 2. Head Clergy Race by Gender over Time.

\begin{tabular}{|c|c|c|c|c|}
\hline Year & Race & Female & Male & Total Race \\
\hline \multirow{6}{*}{1998} & White & $8.6 \%$ & $65.4 \%$ & $74.0 \%$ \\
\hline & & 72 & 548 & 620 \\
\hline & Diverse & $5.0 \%$ & $21.0 \%$ & $26.0 \%$ \\
\hline & & 42 & 176 & 218 \\
\hline & Total Gender & $13.6 \%$ & $86.4 \%$ & $100 \%$ \\
\hline & & 114 & 724 & 838 \\
\hline \multirow{6}{*}{2006} & White & $6.5 \%$ & $58.1 \%$ & $64.6 \%$ \\
\hline & & 72 & 645 & 717 \\
\hline & Diverse & $3.2 \%$ & $32.2 \%$ & $35.4 \%$ \\
\hline & & 36 & 357 & 393 \\
\hline & Total Gender & $9.7 \%$ & $90.3 \%$ & $100 \%$ \\
\hline & & 108 & 1002 & 1110 \\
\hline \multirow{6}{*}{2012} & White & $7.5 \%$ & $57.4 \%$ & $100 \%$ \\
\hline & & 76 & 585 & 661 \\
\hline & Diverse & $6.6 \%$ & $28.6 \%$ & $35.2 \%$ \\
\hline & & 67 & 292 & 359 \\
\hline & Total Gender & $14.0 \%$ & $86.0 \%$ & $100 \%$ \\
\hline & & 143 & 887 & 1020 \\
\hline \multirow{6}{*}{ 1998-2012 } & White & $7.4 \%$ & $59.9 \%$ & $67.3 \%$ \\
\hline & & 220 & 1778 & 1998 \\
\hline & Diverse & $4.9 \%$ & $27.8 \%$ & $32.7 \%$ \\
\hline & & 145 & 825 & 970 \\
\hline & Total Gender & $12.3 \%$ & $87.7 \%$ & $100 \%$ \\
\hline & & 365 & 2603 & 2698 \\
\hline
\end{tabular}

\subsection{Analysis 2-Congregation Characteristics as Indicators of Job Status}

Analysis 2 explored which congregational characteristics were likely to predict clergy gender. Table 3 displays the descriptive statistics for congregational characteristics. Discrete variables are presented as percentages and continuous variables as means. The first two columns for each year show separate results for women and men. The third column shows number of cases and indicates if there is a statistically significant difference between men and women. The focus of the analysis is on the regression results, shown in Table 4 (reported as odds ratios). 
Table 3. Congregation Characteristics-Descriptive Statistics and Bivariate Analyses.

\begin{tabular}{|c|c|c|c|c|c|c|c|c|c|}
\hline \multirow[t]{2}{*}{ Characteristic } & \multicolumn{3}{|c|}{1998} & \multicolumn{3}{|c|}{2006} & \multicolumn{3}{|c|}{2012} \\
\hline & Women & Men & $\mathbf{N}^{\mathrm{a} / \mathrm{P}}$ & Women & Men & $\mathbf{N}^{\mathrm{a} / \mathrm{P}}$ & Women & Men & $\mathbf{N}^{\mathrm{a} / \mathrm{P}}$ \\
\hline & \multicolumn{3}{|c|}{ Means } & \multicolumn{3}{|c|}{ Means } & \multicolumn{3}{|c|}{ Means } \\
\hline$\%$ Female & 66.1 & 59.2 & $673^{*}$ & 69.3 & 63.4 & 873 & 66.9 & 61.6 & $787^{*}$ \\
\hline$\%$ Under age 35 & 27.7 & 30.4 & 683 & 24.3 & 25.2 & 868 & 26.3 & 25.5 & 784 \\
\hline$\%$ Over age 60 & 32.6 & 27.6 & 689 & 33.0 & 34.2 & 869 & 39.8 & 34.8 & 786 \\
\hline$\% 2$ parent fam & 38.4 & 45.7 & 625 & 30.7 & 37.0 & 828 & 33.9 & 38.6 & 746 \\
\hline$\%$ BA & 25.3 & 26.3 & 636 & 45.7 & 25.3 & $805^{* *}$ & 36.7 & 30.6 & 729 \\
\hline$\%$ rich & 2.3 & 4.9 & $635^{* *}$ & 8.8 & 8.0 & 752 & 7.7 & 5.9 & 710 \\
\hline$\%$ poor & 41.5 & 34.6 & 612 & 32.5 & 30.2 & 738 & 31.3 & 37.2 & 705 \\
\hline \# of Adults & 62.3 & 99.8 & $710^{* *}$ & 68.6 & 97.0 & $879 *$ & 62.1 & 94.1 & $792 * *$ \\
\hline Income & 71,189 & 163,631 & $587^{* *}$ & 138,589 & 189,444 & 632 & 242,225 & 258,624 & 675 \\
\hline \multirow[t]{2}{*}{ Total Staff } & 3.8 & 3.2 & 703 & 2.9 & 4.0 & $854+$ & 3.2 & 5.8 & 784 \\
\hline & \multicolumn{3}{|c|}{ Percentages } & \multicolumn{3}{|c|}{ Percentages } & \multicolumn{3}{|c|}{ Percentages } \\
\hline$\geq 80 \%$ White & 62.5 & 73.3 & 690 & 61.1 & 58.4 & 867 & 53.0 & 55.2 & 787 \\
\hline Trad White Lib & 56.6 & 34.4 & $710 *$ & 23.4 & 42.9 & $879 *$ & 41.2 & 23.3 & $792 *$ \\
\hline Trad White Cons & 5.3 & 44.3 & $710^{* * *}$ & 24.6 & 44.7 & $879+$ & 9.7 & 45.0 & $792 * * *$ \\
\hline Trad Black Prot & 30.9 & 17.3 & 710 & 26.4 & 29.5 & 879 & 42.7 & 23.5 & $792 *$ \\
\hline Trad Non-Chstn & 7.2 & 4.0 & 710 & 6.0 & 2.5 & 879 & 6.3 & 8.2 & 792 \\
\hline Theol-Liberal & 24.8 & 12.2 & $701+$ & 37.1 & 6.0 & $860 * * *$ & 27.0 & 12.8 & $785^{*}$ \\
\hline Theol-Mod & 44.5 & 28.7 & 701 & 23.2 & 34.9 & 860 & 45.5 & 23.4 & $785^{*}$ \\
\hline Theol-Conserv & 30.8 & 59.1 & $701^{* *}$ & 39.7 & 59.0 & 860 & 27.5 & 63.9 & $785^{* * *}$ \\
\hline South & 28.6 & 49.0 & $710+$ & 22.1 & 50.1 & $879 * *$ & 55.9 & 49.0 & 792 \\
\hline Urban & 46.7 & 40.6 & 710 & 47.4 & 42.9 & 879 & 51.5 & 49.9 & 791 \\
\hline Rural & 49.8 & 41.6 & 710 & 30.3 & 33.2 & 879 & 43.7 & 30.9 & 791 \\
\hline Suburban & 3.5 & 17.9 & $710^{* * *}$ & 22.3 & 23.9 & 879 & 4.8 & 19.2 & $791 * *$ \\
\hline
\end{tabular}

Notes: Test of significant difference between male and female clergy $+p \leq 0.1{ }^{*} p \leq 0.05 ;{ }^{* *} p \leq 0.01 ;{ }^{* * *} p \leq 0.001$. a Unweighted N.

Table 4. Logistic Regression, Congregational Characteristics Predicting Clergy Gender.

\begin{tabular}{|c|c|c|c|c|c|c|c|c|}
\hline $\begin{array}{c}\text { Dependent } \\
\text { Variable-Clergy Female }\end{array}$ & \multicolumn{2}{|c|}{1998} & \multicolumn{2}{|c|}{2006} & \multicolumn{2}{|c|}{2012} & \multicolumn{2}{|c|}{ 1998-2012 } \\
\hline & & & & & & & & \\
\hline$\%$ Female & 1.040 * & & $1.038^{*}$ & & 1.018 & & $1.028^{* * *}$ & \\
\hline$\%$ Under age 35 & 1.008 & & $0.975+$ & & 1.011 & & 0.999 & \\
\hline$\%$ Over age 60 & 0.999 & & 0.988 & & 0.991 & & 0.995 & \\
\hline$\%$ Two-parent family & 0.995 & & 0.995 & & 1.004 & & 0.997 & \\
\hline$\% \mathrm{BA}$ & 0.991 & & 1.011 & & 1.006 & & 1.004 & \\
\hline$\%$ rich & 0.986 & & 0.989 & & 1.016 & & 0.999 & \\
\hline$\%$ poor & 1 & & 1.002 & & 1.005 & & 1.001 & \\
\hline$>80 \%$ White & 0.939 & & 0.819 & & $5.364 *$ & & 1.639 & \\
\hline In Number of adults & $0.579 *$ & & $0.600 *$ & & $0.483^{* * *}$ & & $0.554^{* * *}$ & \\
\hline ln Income & 1.008 & & 0.99 & & 1.002 & & 0.997 & \\
\hline Total Staff & 1.013 & & 1.018 & & 0.981 & & 1.008 & \\
\hline South & 0.738 & & 0.484 * & & 1.331 & & 0.761 & \\
\hline \multicolumn{9}{|l|}{ Religious Tradition ${ }^{a}$} \\
\hline - White Mainline & $17.545^{* * *}$ & $4.424+$ & $2.309+$ & $3.826+$ & $11.038^{* * *}$ & 0.799 & $5.196^{* * *}$ & 1.763 \\
\hline - Black Protestant & 3.966 & & 0.603 & & $13.821 * *$ & & $2.946 *$ & \\
\hline - Non-Christian & $17.106^{* *}$ & 4.313 & 1.575 & 2.61 & 1.758 & $0.127+$ & $2.748 *$ & 0.933 \\
\hline - White Evangelical & & 0.252 & & 1.657 & & $0.072 * *$ & & 0.339 * \\
\hline \multicolumn{9}{|l|}{ Theology a } \\
\hline - Liberal & $2.726^{*}$ & $2.652 *$ & $2.425^{*}$ & $1.983+$ & $5.888^{* * *}$ & $1.940+$ & $3.104^{* * *}$ & $1.937^{* *}$ \\
\hline - Moderate & 1.028 & & 1.223 & & $3.035^{* *}$ & & $1.602^{* * *}$ & \\
\hline - Conservative & & 0.973 & & 0.818 & & $0.330 * *$ & & 0.624 * \\
\hline \multicolumn{9}{|l|}{ Location ${ }^{a}$} \\
\hline - Urban & $2.917+$ & 2.272 & 0.613 & 0.857 & $2.721+$ & 0.899 & 1.464 & \\
\hline - Rural & 1.284 & & 0.716 & & $3.026+$ & & 1.333 & 0.91 \\
\hline - Suburban & & 0.779 & & 1.397 & & $0.331+$ & & 0.683 \\
\hline Constant & $0.009 *$ & 0.046 & 0.27 & 0.143 & $0.005^{* *}$ & 0.656 & 0 & \\
\hline $\mathrm{N}$ & 508 & 508 & 665 & 665 & 648 & 648 & 1821 & 1821 \\
\hline
\end{tabular}

Notes: Test of significance $+p \leq 0.1 ;{ }^{*} p \leq 0.05 ;{ }^{* *} p \leq 0.01 ;{ }^{* * *} p \leq 0.001{ }^{\text {a }}$ The second column for each model includes results from rotating the reference categories to show different comparisons for religious tradition, theological orientation, and urban/suburban/rural location. 
The regression analysis confirmed the bivariate analysis in that (change over) time is not a significant predictor of clergy gender. The only significant congregation member characteristics were gender balance and racial diversity. In 1998 and 2006, women clergy were more likely to lead congregations with higher percentages of female members, but in 2012 this is no longer significant. In 2012, predominantly white $(>80 \%)$ congregations were five times more likely than somewhat diverse congregations to have a woman head clergy.

Congregation size (number of adults) is significant for all three time points. In 2012, women led congregations with an average of 62 adults, compared to men whose congregations had an average of 94 adult members. Controlling for size, and other factors, congregation income is not significant. However, looking at income alone (Table 5), there was a significant difference in 1998, but not in 2006 or 2012. Therefore, although women tend to be at smaller congregations, there is not a significant difference in the income of congregations led by women compared to men.

Table 5. Job and Clergy Characteristics-Descriptive Statistics and Bivariate Analyses.

\begin{tabular}{|c|c|c|c|c|c|c|}
\hline & \multicolumn{3}{|c|}{2006} & \multicolumn{3}{|c|}{2012} \\
\hline & Women & Men & $\mathbf{N}^{\mathrm{a}} / \mathbf{P}$ & Women & Men & $N^{a} / P$ \\
\hline Clergy Characteristics & \multicolumn{3}{|c|}{ Means } & \multicolumn{3}{|c|}{ Means } \\
\hline Clergy Age & 55.1 & 53.3 & 861 & 54.3 & 55.3 & 789 \\
\hline \multirow[t]{2}{*}{ Clergy Tenure } & 5.2 & 9.0 & $872 * * *$ & 7.0 & 10.0 & $790 *$ \\
\hline & \multicolumn{3}{|c|}{ Percentages } & \multicolumn{3}{|c|}{ Percentages } \\
\hline Clergy Race-White & 66.6 & 64.4 & 871 & 53.0 & 66.7 & 790 \\
\hline Clergy grad school & 55.3 & 59.8 & 872 & 49.4 & 39.5 & 792 \\
\hline Clergy ordained & 87.7 & 94.5 & 875 & 86.2 & 91.9 & 791 \\
\hline Job Characteristics & \multicolumn{3}{|c|}{ Percentages } & \multicolumn{3}{|c|}{ Percentages } \\
\hline Other Ministry staff & 5.4 & 21.4 & $864^{* * *}$ & 13.5 & 17.1 & 789 \\
\hline Paid & 61.9 & 81.5 & $874+$ & 80.0 & 86.6 & 790 \\
\hline Fulltime & 54.8 & 63.5 & 876 & 54.8 & 73.5 & $792 *$ \\
\hline Bi-vocation (Other job) & 28.3 & 39.1 & 876 & 41.4 & 33.1 & 791 \\
\hline Other congregation & 24.5 & 11.9 & 876 & 26.4 & 15.3 & 792 \\
\hline FT, paid, single job & 52.4 & 45.9 & 875 & 42.0 & 48.7 & 791 \\
\hline
\end{tabular}

Notes: Test of significant difference between male and female clergy $+p \leq 0.1 ;{ }^{*} p \leq 0.05 ;{ }^{* *} p \leq 0.01 ;{ }^{* * *} p \leq 0.001$. ${ }^{a}$ Unweighted N.

Both religious tradition and theological orientation are significant predictors of head clergy gender. The regression results show that in 1998, women were more likely to lead in white mainline protestant and non-Christian congregations as compared to white evangelical congregations. In 2012, women were again more likely to lead white mainline protestant congregations, as well as Black protestant congregations. In 1998, theologically liberal congregations were more likely than either moderate or conservative congregations to have a woman leader. In 2006, there was still a significant difference between liberal and conservative, but only a marginally significant difference between liberal and moderate. By 2012, theologically moderate congregations were also more likely than conservative ones to have a female leader.

The 2006 results show congregations in the South being less likely to have women leaders, but there is no significant difference in 1998 or 2012. In 2012, about half of both men and women head clergy served in urban congregations. Only five percent of women, compared to 19 percent of men, were in suburban congregations, leaving 44 percent of women, compared to 31 percent of men in rural congregations. When controlling for other factors in the regression analysis, women were only marginally significantly more likely to be in urban or rural areas rather than suburban.

The specific differences between time periods might indicate possible shifts in congregational characteristics for female head clergy, but the relative consistency between 1998 and 2012 warrants using the combined data set, with a larger sample size and greater statistical power, to summarize the types of congregations more or less likely to have a female leader. Women are less likely than men to 
lead larger, theologically conservative, or white evangelical congregations. Women may also still be more likely to lead congregations with higher percentages of female members.

\subsection{Analysis 3-Senior versus Sole Pastor and Non-Standard Jobs}

Analysis 3 tested whether or not head clergy gender predicts various job status characteristics. Table 5 displays descriptive statistics for job and clergy characteristics. Discrete variables are presented as percentages and continuous variables as means. The first two columns for each year show separate results for women and men. The third column shows number of cases and indicates if there is a statistically significant difference between men and women. Again, the focus of the analysis is on the regression results shown in Table 6 (reported as odds ratios).

Table 6. Logistic Regression. Clergy Characteristics Influencing Job Status Features: 2006 and 2012.

\begin{tabular}{|c|c|c|c|c|c|c|}
\hline & \multicolumn{2}{|c|}{ Senior Pastor } & \multicolumn{2}{|c|}{ Paid } & \multicolumn{2}{|c|}{ Fulltime } \\
\hline & $2006^{a}$ & 2012 & 2006 & 2012 & 2006 & 2012 \\
\hline Female Clergy & $0.410 *$ & 1.412 & $0.389+$ & 0.689 & 0.819 & 0.987 \\
\hline Clergy Age & 0.994 & $1.022+$ & $0.972+$ & 0.99 & $0.947 * * *$ & $0.966^{* *}$ \\
\hline Clergy race-White & 0.58 & $3.457 * *$ & 1.367 & 2.084 & 0.625 & 1.792 \\
\hline Clergy Tenure & 1.011 & 1.004 & 1.012 & $0.967 *$ & $1.030+$ & $1.034 *$ \\
\hline Clergy seminary/grad & 1.083 & 0.804 & $3.045^{* *}$ & 1.115 & 1.517 & 1.299 \\
\hline Clergy Ordained & 0.658 & 0.679 & 1.357 & $5.076^{* *}$ & 1.904 & $2.099+$ \\
\hline ln Number of Adults & $5.889 * * *$ & $6.636^{* * *}$ & $3.162 * * *$ & $2.374 * * *$ & $4.010 * * *$ & $3.249 * * *$ \\
\hline ln Income & 1.046 & 0.984 & 0.998 & 1.002 & 1.03 & $0.950 *$ \\
\hline Trad_-White Mainline & 0.804 & $0.335^{* * *}$ & $5.290 * *$ & $4.745^{* *}$ & 0.886 & $0.509+$ \\
\hline Trad-Black Protestant & $0.143^{* * *}$ & 0.526 & 0.991 & 1.18 & 0.472 & 0.749 \\
\hline Trad-Non-Christian & 0.73 & 1.039 & 0.362 & 1.256 & 2.987 & $0.368+$ \\
\hline Urban & 1.314 & $1.835+$ & 0.695 & 0.939 & 0.758 & 1.183 \\
\hline Rural & 0.829 & 0.766 & 0.598 & 1.318 & 0.863 & 0.836 \\
\hline Constant & $0.000 * * *$ & $0.000 * * *$ & 0.123 & $0.059 *$ & $0.110+$ & $0.108 *$ \\
\hline \multirow[t]{3}{*}{$\mathrm{N}$} & 831 & 780 & 840 & 781 & 842 & 783 \\
\hline & \multicolumn{2}{|c|}{ Other Congregation } & \multicolumn{2}{|c|}{ Bi-vocational } & \multicolumn{2}{|c|}{ Standard Job } \\
\hline & 2006 & 2012 & 2006 & 2012 & 2006 & 2012 \\
\hline Female Clergy & 0.893 & 0.924 & $0.287 *$ & 1.04 & 1.138 & 1.028 \\
\hline Clergy Age & $0.976+$ & 0.984 & $0.954 * * *$ & $0.968 * *$ & 0.989 & 0.995 \\
\hline Clergy race-White & $0.336 *$ & $0.260 * *$ & $0.348^{* *}$ & 1.099 & 1.534 & 1.093 \\
\hline Clergy Tenure & $1.034 *$ & $1.030+$ & 1.016 & 0.999 & 1.009 & 1.001 \\
\hline Clergy seminary/grad & 1.092 & 1.259 & $0.369 * * *$ & $0.611 *$ & $2.542 * * *$ & $1.837^{* *}$ \\
\hline Clergy Ordained & 0.711 & 0.616 & 0.509 & 1.886 & 1.739 & $2.008+$ \\
\hline Clergy Full time & 0.581 & $0.447 *$ & $0.069 * * *$ & $0.144^{* * *}$ & & \\
\hline Clergy Paid & & & 1.757 & $0.439 *$ & & \\
\hline In Num Adults & 0.859 & 0.877 & $0.699 * *$ & $0.738^{* *}$ & $2.482 * * *$ & $2.183^{* * *}$ \\
\hline ln Income & 1.01 & 0.981 & 0.983 & 0.993 & $1.040 *$ & 0.987 \\
\hline Trad_-White Mainline & $1.745+$ & $2.898 * *$ & 0.904 & $0.413 * *$ & 1.071 & 0.999 \\
\hline Trad-Black Protestant & 0.678 & 0.93 & 0.911 & $1.947+$ & 0.695 & $0.422 *$ \\
\hline Trad-Non-Christian & 0.486 & $4.160 * *$ & 2.089 & 0.377 & 0.609 & 0.751 \\
\hline Urban & 0.717 & 0.838 & 1.205 & 1.11 & 0.766 & 0.832 \\
\hline Rural & 1.701 & $3.614 * *$ & 1.681 & 1.051 & 0.692 & 0.734 \\
\hline Constant & 1.946 & 1.441 & $484.363^{* * *}$ & $45.098 * * *$ & $0.014^{* * *}$ & $0.045^{* * *}$ \\
\hline $\mathrm{N}$ & 842 & 783 & 840 & 781 & 841 & 782 \\
\hline
\end{tabular}

Notes: Test of significance $+p \leq 0.1 ;{ }^{*} p \leq 0.05 ;{ }^{* *} p \leq 0.01 ;{ }^{* * *} p \leq 0.001 ;{ }^{a}$ Per Winship \& Radbill, includes interaction between size and religious tradition (not shown in model). White Evangelical and Suburban are the omitted reference categories.

In 2006, among head clergy, only five percent of women were senior pastors, compared to 21 percent of men. By 2012, the difference is no longer significant with 14 percent of women, compared to 17 percent of men, having other ministry staff.

In 2006, 62 percent of women and 82 percent of men were paid, however, the difference is only marginally significant. By 2012, there was an increase in the percentage of paid clergy for both women (80 percent) and men (87 percent). The gap between them is reduced and not significant at all. 
In 2006, women were less likely than men to be bi-vocational. By 2012, there are no significant differences between women and men in the likelihood of having a nonstandard employment form. Relatively more women (41 percent) than men (33 percent) were bi-vocational, but the difference is not significant. When looking at fulltime status alone (Table 5), there is a significant difference with 55 percent of women compared to 74 percent of men, having fulltime positions. However, when controlling for other factors in the regression analysis, the difference is not significant. While women are less likely to be fulltime, it is indirectly due to gender, but rather, because they are more likely to be at congregations that do not support a fulltime clergy.

Several control variables were consistent predictors for different job statuses. The size of the congregation is significant across almost all regression models, confirming the importance of this measure in assessing congregational status and characteristics that describe clergy position structure, pay, and benefits. Congregational income has a significant influence on the position being fulltime. The results show that as congregation income goes up, the likelihood of a fulltime head clergy goes down slightly. This is perhaps an unusual finding and suggests a complex relationship between congregation size and income. It is also possible that the imputed income values are obscuring this particular result. The clergy position being fulltime is an important indicator for the clergy being less likely to serve another congregation or have another secular job. Older clergy are less likely to be bi-vocational and more likely to work part-time. In 2006, clergy with graduate training were almost three times as likely as those without, to be paid. However, there is no significant difference in 2012. In 2012, clergy who were ordained were five times as likely as non-ordained clergy to be paid, and twice as likely to work full-time. Clergy in rural congregations were almost four times as likely as those in the suburbs to serve another congregation. White evangelical congregations are more likely to have a senior pastor than white mainline or Black protestant congregations. Compared to white evangelical clergy, white mainline head clergy are more likely to serve another congregation and be bi-vocational. Non-Christian clergy are also more likely to serve multiple congregations.

\section{Discussion and Conclusions}

My research analyzed recent data on religious congregations to continue to assess the status of women clergy and evaluate gender stratification in the top-tier of the clergy occupation, among clergy who are the leaders of religious congregations. A strength of this article is it provides a broad, national, multi-denominational overview of the recent status of women head clergy. The corresponding limitation is that does not address specific factors more relevant to particular denominations or religious traditions. This research can provide a new baseline for ongoing denominational and clergy-level research regarding gender inequity.

Women are still under-represented in the top clergy position, even when denominational doctrines and policies allow them to be head clergy. Beyond this primary indicator of gender occupational inequality, it is important to recognize that the top-tier position of head clergy is also stratified. Leading a larger, resource-rich, congregation in the suburbs with other ministry and fulltime staff and members who reflect a higher socio-economic status is a higher-ranked position than leading a small, poor, rural or inner-city congregation with no other fulltime staff and with members who might themselves have fewer resources.

The senior pastor role and congregation size are primary indicators in defining different status levels within the clergy occupational structure, specifically within the role of head clergy. Based on these factors, there are mixed results regarding gender equity among head clergy. Women's representation among senior pastors improved from 1998 to 2012 but their representation in larger congregations remains unequal. While the average size of congregations women lead remained the same between 1998 and 2012, in 2012 those size congregations are more likely to have other ministry staff.

Consistent with prior research, women clergy are more likely to be in white mainline protestant and non-Christian congregations. These congregations tend to be larger than white evangelical or Black protestant congregations which could give women more opportunities for larger congregations, 
but women tend to be at smaller congregations compared to men within each religious tradition. The issue of size highlights the importance of continued research on multiple levels regarding clergy placement related to gender. This national-level, multi-denominational study covering three time frames provides the bigger picture. Continued research on the denominational level is needed to explore why congregations whose denominational doctrines and policies are open to women head clergy continue to exhibit patterns of women being at smaller, lower status, congregations. Updated research is also needed to follow up on studies such Lehman (1981) which focused on member expectations which might differ from denominational leadership expectations.

Shifting the focus from congregational characteristics to job status characteristics, including those describing non-standard forms of employment, the picture for women head clergy is more positive. Men and women are equally likely to work fulltime and to be paid. By 2012 there is no significant difference between men and women in the likelihood of serving multiple congregations or being bi-vocational. However, congregation size/status is a potential factor regarding rate of pay. Carroll (2006) finding that men and women tend to receive equal pay for similar status positions is encouraging, but since women still tend to be in smaller congregations, they are likely to be receiving lower rates of pay. A limitation of the NCS data for clergy research is that it does not include clergy salary information.

My results for 1998 are different from prior studies using the 1998 NCS data and show a somewhat better picture regarding gender equity for women head clergy. The difference in results is most likely because I excluded Roman Catholic, Southern Baptist, and other denominations that do not ordain women. Adams (2007) excluded Roman Catholics, but not Southern Baptist or other groups. Konieczny and Chaves (2000) explored a general profile of women's congregations so they included all denominations. I also operationalized some variables differently than Konieczny and Chaves. I used the original measures of member demographics, recorded as percentages. Konieczny and Chaves recoded these into binary values indicating whether the measures were above or below certain thresholds.

A more thorough intersectional analysis (considering the combined effects of race and gender) would require over-sampling of congregations with women head clergy to have adequate sub-samples of white and racially diverse women. An alternative approach could be to focus on surveying only women head clergy and comparing the effects of race. However, this would not capture the full intersectional perspective of the combined influence of race and gender, rather it would be exploring the effects of race within gender.

Future research could also explore the gender-size issue in more detail, specifically related to research on mega-churches. The apparent rise in additional ministry staff at somewhat smaller congregations could be another interesting avenue to explore.

Conflicts of Interest: The author declares no conflict of interest.

\section{References}

Adams, Jimi. 2007. Stained Glass Makes the Ceiling Visible: Organizational Opposition to Women in Congregational Leadership. Gender and Society 21: 80-105. [CrossRef]

Adams, Tracey L. 2005. Feminization of Professions: The Case of Women in Dentistry. Canadian Journal of Sociology 30: 71-94.

ATS. 2015. 2015-2016 Annual Data Tables. Pittsburgh: The Association of Theological Schools.

Bendl, Regine, and Angelika Schmidt. 2010. From 'Glass Ceilings' to 'Firewalls'-Different Metaphors for Describing Discrimination. Gender, Work and Organizations 17: 612-34. [CrossRef]

Bielby, William T. 2000. Minimizing Workplace Gender and Racial Bias. Contemporary Sociology 29: 120-29. [CrossRef]

Carroll, Jackson W., Barbara Hargrove, and Adair T. Lummis. 1981. Women of the Cloth. Cambridge: Harper \& Row Publishers. 
Carroll, Jackson W. 2006. God's Potters: Pastoral Leadership and the Shaping of Congregations. Grand Rapids: William B. Eerdmans Publishing Company.

Chang, Patricia M. Y., and Viviana Bompadre. 1999. Crowded Pulpits: Observations and Explanations of the Clergy Oversupply in the Protestant Churches, 1950-1953. Journal for the Scientific Study of Religion 38: 398-410. [CrossRef]

Chang, Patricia M. Y. 2004. Assessing the Clergy Supply in the 21st Century. Durham: Duke Divinity School.

Chang, Patricia M. Y. 2005. Factors Shaping Clergy Careers: A Wakeup Call for Protestant Denominations and Pastors. Edited by J. W. Carroll. Durahm: Duke Divinity School.

Charlton, Joy. 1997. Clergywomen of the Pioneer Generation: A Longitudinal Study. Journal for the Scientific Study of Religion 36: 599-613. [CrossRef]

Chaves, Mark, Mary Ellen Konieczny, Kraig Beyerlein, and Emily Barman. 1999. The National Congregations Study: Background, Methods, and Selected Results. Journal for the Scientific Study of Religion 38: 458-76. [CrossRef]

Chaves, Mark, and Shawna L. Anderson. 2008. Continuity and Change: Introducing the Second Wave of the National Congregations Study. Sociology of Religion 69: 415-40. [CrossRef]

Chaves, Mark, and Shawna L. Anderson. 2014. Changing American Congregations: Findings from the Third Wave of the National Congregations Study. Journal for the Scientific Study of Religion 53: 676-86. [CrossRef]

Chaves, Mark, Shawna L. Anderson, and Alison Eagle. 2014. National Congregations Study. Cumulative Data File and Codebook. Durham: Duke University.

Cohen, Philip N., Matt L. Huffman, and Stefanie Knauer. 2009. Stalled Progress?: Gender Segregation and Wage Inequality among Managers, 1980-2000. Work and Occupations 36: 318-42. [CrossRef]

Cook, Alison, and Christy Glass. 2014. Women and Top Leadership Positions: Towards an Institutional Analysis. Gender, Work and Organizations 21: 91-103. [CrossRef]

Finlay, Barbara. 1996. Do Men and Women Have Different Goals for Ministry? Evidence from Seminarians. Sociology of Religion 57: 311-18. [CrossRef]

Gatta, Mary L., and Patricia A. Roos. 2005. Rethinking Occupational Integration. Sociological Forum 20: 369-402. [CrossRef]

Kalleberg, Arne L. 2000. Nonstandard Employment Relations: Part-Time, Temporary, and Contract Work. Annual Review of Sociology 26: 341-65. [CrossRef]

Kalleberg, Arne L., Barbara F. Reskin, and Ken Hudson. 2000. Bad Jobs in America: Standard and Nonstandard Employment Relations and Job Quality in the United States. American Sociological Review 65: 256-78. [CrossRef]

King, Gail Buchwalter. 1990. The Factbook on Theological Education for the Academic Years 1988-1989 and 1989-1990. Pittsburgh: The Association of Theological Schools in the United States and Canada.

Konieczny, Mary Ellen, and Mark Chaves. 2000. Resources, Race, and Female-Headed Congregations in the United States. Journal for the Scientific Study of Religion 39: 261-71. [CrossRef]

Lehman, Edward C. 1981. Organizational Resistance to Women in Ministry. Sociological Analysis 42: 101-18. [CrossRef]

Lehman, Edward C. 2002. Women's Path into Ministry: Six Major Studies. Durham: Duke Divinity School.

McDuff, Elaine M., and Charles W. Mueller. 1999. Social Support and Compensating Differentials in the Ministry: Gender Differences in Two Protestant Denominations. Review of Religious Research 40: 307-30. [CrossRef]

McDuff, Elaine M., and Charles W. Mueller. 2000. The Ministry as an Occupational Labor Market: Intentions to Leave an Employer (Church) Versus Intentions to Leave a Profession (Ministry). Work and Occupations 27: 89-116. [CrossRef]

McDuff, Elaine M. 2001. The Gender Paradox in Work Satisfaction and the Protestant Clergy. Sociology of Religion 62: 1-21. [CrossRef]

Michaelson, Ethan. 2013. Women in the Legal Profession, 1970-2010: A Study of the Global Supply of Lawyers. Indiana Journal of Global Legal Studies 20: 1071-137. [CrossRef]

Mueller, Charles W., and Elaine M. McDuff. 2002. “Good" Jobs and "Bad" Jobs: Differences in the Clergy Employment Relationship. Review of Religious Research 44: 150-68. [CrossRef]

Nesbitt, Paula D. 1993. Dual Ordination Tracks: Differential Benefits and Costs for Men and Women Clergy. Sociology of Religion 54: 13-30. [CrossRef] 
Nesbitt, Paula D. 1997a. Gender, Tokenism, and the Construction of Elite Clergy Careers. Review of Religious Research 38: 193-210. [CrossRef]

Nesbitt, Paula D. 1997b. Feminization of the Clergy in America. New York: Oxford University Press.

Nesbitt, Paula D. 1997c. Clergy Feminization: Controlled Labor or Transformative Change? Journal for the Scientific Study of Religion 36: 585-98. [CrossRef]

Piore, Michael. 1971. The Dual Labor Market. In Problems in Political Economy: An Urban Perspective. Edited by D. M. Gordon. Lexington: D.C. Heath.

Reskin, Barbara F. 2000. The Proximate Causes of Employment Discrimination. Contemporary Sociology 29: 319-28. [CrossRef]

Reskin, Barbara F., and Patricia A. Roos. 1990. Job Queues, Gender Queues: Explaining Women's Inroads into Male Occupations. Philadelphia: Temple University Press.

Roth, Louise M. 2004. Engendering Inequality: Porcesses of Sex-Segregation on Wall Street. Sociological Forum 19: 203-28. [CrossRef]

Ryan, Michelle K., and S. Alexander Haslam. 2007. The Glass Cliff: Exploring the Dynamics Surrounding the Appointment of Women to Precarious Leadership Positions. Academy of Management Review 32: 549-72. [CrossRef]

Skuratowicz, Eva, and Larry W. Hunter. 2004. Where Do Women's Jobs Come From?: Job Resegregation in an American Bank. Work and Occupations 31: 73-110. [CrossRef]

Steensland, Brian, Jerry Z. Park, Mark D. Regenerus, Lynn D. Robinson, W. Bradford Wilcox, and Robert D. Woodberry. 2000. The Measure of American Religion: Toward Improving the State of the Art. Social Forces 79: 291-318. [CrossRef]

Sullins, Paul. 2000. The Stained Glass Ceiling: Career Attainment for Women Clergy. Sociology of Religion 61: 243-66. [CrossRef]

Taylor, Marvin J. 1979. The Fact Book on Theological Education: 1978-1979. Pittsburg: The Association of Theological Schools.

Tolbert, Pamela S., and Richard H. Hall. 2016. Organizations: Structures, Processes, and Outcomes. New York: Routledge.

Tomaskovic-Devey, Donald. 1993. Gender E Racial Inequality at Work: The Sources and Consequences of Job Segregation. Ithaca: Cornell University Press.

Wildhagen, Tina, Charles W. Mueller, and Minglu Wang. 2005. Factors Leading to Clergy Job Search in Two Protestant Denominations. Review of Religious Research 46: 380-402. [CrossRef]

Williams, Joan. 2000. Unbending Gender: Why Family and Work Conflict and What to Do About It. Oxford: Oxford University Press.

Wind, James P., and Gilbert R. Rendle. 2001. The Leadership Situation Facing American Congregations: An Alban Special Report. Bethesda: Alban Institute.

Winship, Christopher, and Larry Radbill. 1994. Sampling Weights and Regression Analysis. Sociological Methods and Research 23: 230-57. [CrossRef]

Zickmund, Barbara Brown, Adair T. Lummis, and Patricia M. Y. Chang. 1998. Clergy Women: An Uphill Calling. Louisville: Westminster John Knox Press.

Zyniewicz, Matthew, and Daniel Aleshire. 1999. The Fact Book on Theological Education: For the Academic Year 1998-1999. Pittsburg: The Association of Theological Schools.

(C) 2017 by the author. Licensee MDPI, Basel, Switzerland. This article is an open access article distributed under the terms and conditions of the Creative Commons Attribution (CC BY) license (http://creativecommons.org/licenses/by/4.0/). 